\title{
Explanatory Possibilities \\ of G.P. Mel'nikov's System Linguistics: Updating of Unknown
}

\author{
Olga I. Valentinova, Sergey Iu. Preobrazhenskii \\ and Mikhail A. Rybakov* \\ Peoples' Friendship University of Russia \\ 6 Miklukho-Maklai Str., Moscow, 117198, Russia
}

Received 27.05.2017, received in revised form 04.12.2017, accepted 14.12.2017

The article discusses some linguistic examples never previously presented in the form of full texts. Taken from lectures and spoken communications examples illustrate the explanatory potential of the ingenious linguistic theory of a unique but unfortunately little-known Russian linguist G.P. Mel 'nikov. The purpose of the research is to update and represent for linguistic professional community the central idea of G.P. Mel'nikov's conception - the idea of explaining the phenomena of one level of language by facts of the other levels. The authors have based their work on the systemic method of linguistic theory constructing and the explored by G.P. Mel'nikov doctrine of external and internal determinants of languages. The results can be used in linguistic typology and theoretical linguistics for explanation of a wide range of language phenomena.

Keywords: explanatory linguistics, determinants of language, language system, linguistic typology, systemic method, systemic linguistics.

DOI: 10.17516/1997-1370-0196.

Research area: philology.

\section{Introduction}

G.P. Mel'nikov's systemic linguistics which, according to scientific ambitions of its author, claimed to have methodological priority in linguistics in general and particularly in linguistic typology, at present cannot be estimated another way as an epistemic marginality. But at the time when previously considered leaders of linguistic science embodying genuine linguistic progress, proclaimed linguistics a "theoretically exhausted" field of knowledge, G.P. Mel'nikov's systemology could fill the seeming void (cf: "Once (in 1989) I asked the outstanding linguist Igor Mel'chuk, what was happening to his science. He answered (manifesting no pleasure), that some sciences were theoretically exhausted, including linguistics" (Smirnov, 1995: 3)). Symptomatically, in those critical 1990ies the concept of "dynamic" typology by A.E. Kibrik was published; his monograph (Kibrik, 1992) contains references to Iu.P. Rozhdestvenskii's "The Typology of Word" (Rozhdestvenskii, 1969) which to a large degree

(C) Siberian Federal University. All rights reserved

* Corresponding author E-mail address: ovalentinova@yandex.ru; preobrag@mail.ru; rybakov_ma@pfur.ru 
reflects G.P. Mel'nikov's theoretical views. Thus, G.P. Mel'nikov's theory cannot be regarded as completely forgotten and ignored by the scientific "mainstream". In those years, critical for Russian linguistics, G.P. Me'lnikov acquired allies, such as the phonologist E.F. Kirov, typologist A.A. Kretov, Russian syntax researcher M.Iu. Fedosiuk.

Presently, judging by the activeness of publishers and Internet portals, the Russian linguistic community has regained a certain interest for the scientific heritage of the linguistic systemology founder. Possibly, the scholars are mainly attracted by the explanatory and prognostic potential of the "system linguistics". G.P. Mel'nikov used to test his guesses and ideas in the student audience; it helped manifest the bright and original persuasiveness of the illustrative analogies, which sometimes disappeared in his few monographs, the fact that made editors complain: "This circumstance (limited volume. - authors of the article) must have denied the author the opportunity to use his original manner of presenting his ideas, the manner for which he is famous among the audience at conferences, congresses, seminars and lectures, where he illustrates each of his propositions by demonstrative pictures and examples from various scientific fields, branches of technology, from social and everyday situations" (Kosarev, 1978: 4). The authors of the present paper once comprised that very student audience of G.P. Mel'nikov and their object as they see it is actualizing some of the scientist's speculations which remain in their memories, which have never been published as completed texts, but fully realize the explanatory and prognostic potential of his "system linguistics".

\section{The conceptual basis of systemic linguistics}

G.P. Mel'nikov characterized the typological structure of Semito-Hamitic languages in several relatively small scientific articles: "Interdependence of tiers in languages of Semitic system" (Mel'nikov, 1965) and "Relation of Semito-Hamitic languages to Indo-European and Ibero-Caucasian languages from the position of system linguistics" (Mel'nikov, 1977). But later he often resumed the topic in his oral reports. For instance, there exists a record of his lecture of 1987, addressed to a wide audience. About a year before delivering the mentioned lecture, G.P. Mel'nikov had illustrated some principles of the "Semitic language system", namely, the following one: “... we have two types of signs; one type expresses actions and is basic in all respects, other signs are modifiers of those basic ones. So, if we trace the development of the Semitic language system and compare it to the Indo-European system, we shall see that in the Indo-European systems the basic roots sometimes concern action, and such roots often prevail, but there is plenty of other roots (not verbal); as for Semitic languages, there a process took place of throwing away roots not naming action; they were either forgotten or reinterpreted, as the result, only words naming actions remained" (Mel'nikov, 1977: 139). This illustration appears to have had an independent meaning, as it stated isomorphism of semiotic systems of different substantial nature (verbal and visual) performing similar communicative function in the language community where one of the Semito-Hamitic languages was used. G.P. Mel'nikov analyzed the visual system of the ancient Egyptian fresco. The first thing to note was the contradictory combination of visual statics and semiotic dynamics: for any human figure, there was an obligatory angle canon (shoulders horizontal, both feet stiff in pace, both hands shown, on the face in profile the eye shown en face). In such a way, the pictures of people-doers are verbalized, turned into visualized "verbs" different positions of hands and feet are semantic specifiers of an iconic sign of what the figure is 
doing - shooting, going, running, carrying water etc. The conventional elements of the picture are in analogy to the consonant base of the SemitoHamitic root (it is well-known that the ancient Egyptian language, ousted latter by the Egyptian dialect of the Arabic, comprises a separate branch of Semito-Hamitic language). As for the areas of relative freedom in the frescos, they are like vocal modifiers: in Semitic languages, firstly, the changing vocal structure of the root consisting of three unchanging consonants, specifies the meaning or conveys a grammar category. In the horizontal picture placed on a wall, the most stable elements are the most standardized large figures, which can also be compared - besides the comparison to the stable consonant base of a Semitic root - to the verbal-attributive predicate of the Semitic sentence. As for the more variable from the point of view of the visual canon elements of the picture, on this level of comparison they will be akin to nominal modifiers of the message.

According to G.P. Mel'nikov's conception, changes in the size of a language community, in the degree of its homogeneity or non-homogeneity, in the frequency and character of communication depending on the conditions and way of life of the native speakers, for instance, nomadic or settled, cause internal reconstruction of language leading to change of language type. For instance, gradual growth of a minimal isolated language community, in which initially "everybody knows about everything" and uses phrase-sentences, with a lessened possibility of describing the situation in the whole community and with a need of describing only one fragment of the general state of matters and only one participant, not necessarily known by the others, leads at first to appearance of utterances consisting of several phrase-sentences - both complex and compound, and then to an utterance the components of which become habitual sentence parts. Thus, the growth of a language community leads to the change of the language system: from incorporating, usually class language, with a phrase sentence, to an utterance consisting of several phrase sentences and, finally, to the ergative language with traditional parts of sentence. Establishing connection of external factors of a language existence, its external determinant, with the characteristics of a language system, G.P. Mel'nikov singled out the most stable quality of the language system of every morphological type (its internal determinant), which manifests itself on the highest tier of language and is supported by the peculiarity of all deeper tiers. The remark, thrown by G.P. Mel'nikov during one of his lectures: "Let me read the chapter on phonetics of any language and I'll tell you how the whole language is arranged" is neither a hyperbole, nor a metaphor (G.P. Mel'nikov had never been a poseur or an "aesthete"). It is a fact the reliability of which is obvious for everyone who has read his works or had a chance of communicating with him. G.P. Mel'nikov's doctoral theses "System typology of languages" (Mel'nikov, 2003), his "main linguistic work" which has reflected the results of many-year research of one of the most outstanding scholars of linguistics, was prepared for print by professor L.G. Zubkova (Zubkova, 2003) already after G.P. Mel'nikov's death. But a lot of the scholar's observations expressed at lectures or in private talks with colleagues, sometimes casually, during the pause between lessons or on the way home, have remained beyond the limits of this main book and other works by G.P. Mel'nikov. Were any of these observations included into inventory, or just taken into consideration by science, it could change the vector of development of various fields of linguistics, in which the founder of the modern systemic linguistics himself did not work directly, from descriptive into explanatory.

The explanatory potential of the method worked out by G.P. Mel'nikov covers the 
language substance on every grade, making the method itself universal. The external conditions of life of a language community explain not only the differences in typological characteristics of languages, but also dialect peculiarities of a single language. To make it sure, it is necessary to immerse into G.P. Mel'nikov's system which, as a system aimed to receiving the complete knowledge, possesses a characteristic closeness caused by general interdependence and interrelation of its statements.

Defining the Russian dialect verb forms думаш, думат, corresponding to literary and other dialect forms дум[айеш], дума[йет] because of "morphologization of processes on the junction of stem and inflection of verbs" does not mean explaining the cause of their appearance.

A dialect of the Russian language, on the one hand, turns out to be a dialect of a language the system of which is determined by the necessity of maintaining a very large language community retaining homogeneity and leading a settled way of life; on the other hand, the dialect itself is not spread among all Russian native speakers.

According to G.P. Mel'nikov, in the Russian language, in the present external circumstances, when communication of everyone with everyone is impossible due to an extremely large language community, dispersed on an enormous territory, the mechanism of sharing information should imply constant verification of what the speaker wanted to say with what the listener has understood. Such a possibility is given by a nominative system with well-developed inflecting technique.

The ending of the noun in nominative case and the personal ending of a finite verb denote the same person: парень думаЕT (The boy is thinking). The ending of the nominative case парен- $\boldsymbol{b}$ represents a reduced simplest clause "Некто делает" (Somebody is doing), the finite form of the verb also represents a reduced predicative unit: the stem of the verb names an action, and the personal ending дума[ц̆-ET] names the person performing the action.

Such technique - first subject, then action gives a chance of collating the uttered and the comprehended. First the named subject allows the recipient to assume, judging from the knowledge of general qualities of the subject, what action the latter can perform, and the action named subsequently indicates (by way of ending) the person which is the subject of the named action: дума[й-ET] - 'дума-ОН'.

In conditions of limited communication reduced to everyday life, when both the speaker and the listener know equally well who is the initiator of the described action, the necessity of confirming the correct understanding of who is in question is diminished, and the form думат, characteristic of some Russian dialects, appears.

In the light of the presumed by G.P. Mel'nikov's conception necessity of searching the reason of appearance, change or disappearance of each language phenomenon and fact, we change our ideas of "akanye", nondistinction of non-close vowels - a dialect quality received by the literary Russian in spite of the possibility of historic choice between akanye and okanye, the latter meaning distinction of non-close vowels in the position of the first pre-accented syllable. Akanye, unlike okanye, allows to express an extremely wide amplitude of emotion by way of intonation. Now we can explain the appearance and fixation of akanye in the literary Russian by the law of expression in action. One of the two universal laws of language evolution had worked (the other one is the law of psychic energy economy). Appearance of new forms is caused by the necessity of expressing meanings unexpressed in the language by other means and forms. Akanye gives the intonation new expressive opportunities. 
Generally, minimal change of form leads to change of meaning. Change of form is always connected with change of meaning, and this connection is fully obligatory. At such understanding of correlation between form and meaning, when asked: "Which form is correct, профессоры or профессора́?”, we shall answer: it depends on what you want to say. If you consider the professors as a "disjoint set" in which the personality of each professor is important, you say профессорЫI. If you mean not a "disjoint set", but a homogeneous mass, you say профессорA. Where it is said nрофессоры, as it was in the Russian Empire, the social status of a professor is incomparably higher than there where the form npopeccopá, is habitually used, no matter whether the speakers understand the difference in meaning or think in standard stereotypes, like an obsolete form/a modern form.

Explaining phenomena of a certain language level by facts of other levels discloses the central idea of G.P. Mel'nikov's linguistic theory. In polemics with the followers of structural linguistics, G.P. Mel'nikov had always argued the interdependence of language levels, showing by way of examples their being organic parts (subsystems) and having their own functions within the whole suprasystem, i.e. language. He did not reject the well-known level model of language, but considered it one of the aspects of the system model which structural linguists never attempted to build. Following F. de Saussure, they considered language "in itself and for itself", never turning to its external functions and conditions of existence. Structural linguists applied this autonomy principle to investigating separate levels. As for typological classifications, they, if considered at all, were regarded as completely independent from one another.

In his work of 2000, "System typology of languages: synthesis of morphological and phased classifications of languages" G.P. Mel'nikov, as it is clear from the title, synthesized the synchronic and diachronic aspects of typological classification and thus put an end to the generally accepted and fruitless opposing of "morphological classification" to "phased classification by stage". It has become clear that linguistic typology cannot be only synchronic, and historic linguistics cannot be only descriptive and local, also the interrelation of morphological and syntactic structures of languages was shown in the light of Mel'nikov's initial idea that both structures of the external form of language are generated by its internal form; the latter is "the essence of the language system manifesting itself through numerous observable projections, including "morphological" and "phased" classifications of language types" (Mel'nikov, 2000: 52).

The founder of the system theory of language sees the initial cause of language structure changes in the external factors determining the conditions of communication in a certain language. Then he builds a chain of causes and consequences: conditions of communication in a language community information needs of the community members typical occasions and plots of communication typical language meanings capable of hinting on necessary sense (the nominative angle of the language) - typical form of articulating the given meanings (syntactic and morphological type of language). The abstract model was deduced by G.P. Mel'nikov from a system of examples, each of them was perceived by listeners as a discovery. Why ask someone who has never studied Polynesian languages, whether vowels or consonants are semantic in them? - To show that at a certain mental effort the offered conception will give conclusive knowledge of high quality, even if we are not aware of separate language facts. The noise of wind and ocean prevent from hearing consonants, and quickness and quality of understanding affects not only concord, but also 
the life of people living on small islands scattered in the ocean and every day going to sea in little boats to fish or to reach another island.

Change of such parameters as the size of a language community and the degree of continuity of the social experience leads to the change of language type in the direction: incorporating language (in morphological and syntactic aspects non-distinctive of these levels) - incorporating ergative language (in morphological aspect incorporation is partial, the object of an utterance is singled out) - agglutinative ergative language (terminative and attributive angle) - agglutinative nominative language (the subject is singled out) inflective nominative language (the subject comes out to the foreground, all parts of the sentence tend to morphological formalization, eventivity is the main trait of the nominative angle) - isolating nominative language (parts of the sentence are devoid of morphological formalization, the situation is depicted in an outline, in a general contour).

\section{Conclusion}

G.P. Mel'nikov has proved that syntactic and morphological classifications, although they consider different dimensions of language, are parts of one system and are not completely independent: incorporating language cannot be nominative, inflective and isolating languages cannot be ergative. At the same time, there is no direct system of correspondences here: firstly, there are three morphological types that can be syntactically nominative; secondly, an agglutinative language can be both ergative and nominative. This is natural for G.P. Mel'nikov conception, because two classifications based on external forms of different levels, are explained not only through one another, but mostly through a deeper notion of the internal form of the language. Incorporation, for instance, is directed on a detailed description of a situation, not of a dynamic event including subject and object of action. The tendency of language to create a certain image, called by G.P. Mel'nikov the determinant of a language, depends not on the formal structures of the language but on the typical informational need of the participants of communication. Moreover, it is the factor inducing the language to fix some formal structures as canonic.

\section{References}

Kibrik, A.E. (1992). Ocherki po obshchim i prikladnym voprosam iazykoznaniia [Essays on general and applied linguistic questions]. Moscow, Izdatel'stvo Moskovskogo Universiteta, 336 p.

Kosarev, Iu.G. (1978). Predislovie redaktora [Preface of the editor], In Mel'nikov, G.P. Sistemologiia i iazykovye aspekty kibernetiki [Systemology and linguistic aspects of cybernetics]. Moscow, Sovetskoe radio, 5-12.

Mel'nikov, G.P. (1965). Vzaimoobuslovlennost' struktury iarusov v iazykakh semitskogo stroia [The interdependence of level structure in languages of Semitic formation], In Semitskie iazyki [Semitic Languages], Issue 2, Part 2. Moscow, Nauka, 793-817.

Mel'nikov, G.P. (1977). Otnoshenie semito-khamitskikh iazykov k indoevropeiskim I iberokavkazskim s pozitsii sistemnoi lingvistiki [The relation of Semitic languages to Indo-European and Iberic-Caucasian from the point of view of the systemic linguistics], In Proceedings of the $3 d$ AllUnion Semitologist Conference. Tbilisi, 138-141.

Mel'nikov, G.P. (2000). Systemnaia tipologiia iazykov: sintez morfologicheskoi klassifikatsii so stadial'noi [The systemic typology of languages: the synthesis of morphological and stadial classifications]. Moscow, Izdatel'stvo RUDN, 90 p. 
Mel'nikov, G.P. (2003). Systemnaia tipologiia iazykov [The systemic typology of languages]. Moscow, Nauka, 392 p.

Mel'nikov, G.P. The audience constructs the base of the Semitic Languages. Available at: http:// philosophystorm.org/melnikov-gp-auditoriya-konstruiruet-osnovu-semitskikh-yazykov (accessed 21 April 2017).

Rozhdestvenskii, Iu.V. (1969). Tipologiia slova [The typology of word]. Moscow, Vysshaia Shkola, $286 \mathrm{p}$.

Smirnov, I.P. (1995). Predislovie ko vtoromu izdaniiu [Preface to the $2 d$ edition], In Porozhdenie interteksta [The creation of inertext]. Sankt-Peterburg, Izdatel'stvo SPBGU, 3-8.

Zubkova, L.G. (2003). O glavnom lingvisticheskom trude G.P. Mel'nikova [On the main linguistic work of G.P. Mel'nikov], In Mel'nikov, G.P. Systemnaia tipologiia iazykov [The systemic typology of languages] Moscow, Nauka, 6-17.

\section{Объяснительные возможности}

системной лингвистики Г.П. Мельникова:

актуализация неизвестного

О.И. Валентинова, С.Ю. Преображенский, М.А. Рыбаков

Российский университет дружбы народов

Россия, 117198, Москва, ул. Миклухо-Маклая, 6

В статье обсуждаются некоторые лингвистические примеры, никогда ранее не публиковавшиеся в виде полных текстов. Взятые из лекиий и устных сообщений примеры иллюстрируют объяснительный потенциал оригинальной лингвистической теории уникального, но, к сожалению, малоизвестного русского лингвиста Г.П. Мельникова. Цель данного исследования - актуализировать и представить профессиональному сообществу лингвистов центральную идею кониепиии Г.П. Мельникова - идею объяснения феноменов одного уровня языка фактами других уровней. В своей работе авторы опираются на системный метод построения лингвистической теории и разработанную Г.П. Мельниковым доктрину внешней и внутренней детерминанты языка. Результаты исследования могут быть использованы в лингвистической типологии и теоретической лингвистике для объяснения широкого круга языковых явлений.

Ключевые слова: объяснительная лингвистика, детерминанты языка, языковая система, лингвистическая типология, системный метод, системная лингвистика.

Научная специальность: 10.00.00 - филологические науки. 